\title{
Evolution of Knowledge on the Etiological Diagnosis of Chagasic Infection
}

\author{
Alejandro $\mathbf{O}$ Luquetti \\ Hospital das Clínicas, Universidade Federal de Goiás, Caixa Postal 372, 74001-070 Goiânia, GO, Brasil
}

Key words: Chagas disease - diagnosis

Very early after the publication of Chagas, in 1909 , methods for the parasitological diagnosis (xenodiagnosis, Brumpt 1914) and serological diagnosis (Guerreiro \& Machado 1913) were already available. More interesting, both methods are still beeing used, 85 years later. The same method used until now for parasitological diagnosis of the acute phase, was performed by Chagas (wet blood smear, as well as animal inoculation). Of course, in the meantime, other techniques became available for etiological diagnosis. We may divide the improvments in diagnosis in several periods: on the first, until 1960, diagnosis was performed basically with the same tools, i.e. xenodiagnosis for the parasitological and complement fixation for the serological diagnosis of the chronic phase. The second period may be delimitated between 1960 and 1975, in which major advances were performed. For the acute phase, a major advance was the Strout method for hemoflagellates (1962), and after, the microhematocrit, mainly for newborns and children. Camargo et al. (1974) described the IgM-IFI as a secure method for acute (including transfusionally acquired) phase. For the chronic phase, parasitological diagnosis include now hemoculture (Chiari et al. 1966), disputing sensitivity with xenodiagnosis, in a fight that runs until today. Serological diagnosis was firmly established, first with the standardization of the complement fixation reaction (CFR) by Almeida and Fife (1974) and also with the introduction of indirect hemagglutination (Cerisola et al. 1962) and indirect immunofluorescence (Camargo et al. 1966), techniques that are prefered today to the CFR. The third period, of, again, major improvments, was from 1975 until today. Parasitological diagnosis received a great help with the PCR amplification

Fax.: +55-62-202.1500. E-mail: luquetti@hc.ufg.br Received 9 June 1999

Accepted 9 August 1999 techniques (Sturm et al. 1989, Moser et al. 1989). Results obtained with hemocultures were improved after substancial modifications (Chiari et al. 1989, Luz et al. 1994). Serological diagnosis included ELISA after Voller description (1975), and several purified antigens started to be used, as GP90kD, GP72kDa, GP25kDa, and shortly after, recombinant antigens and synthetic peptides were used and evaluated in several multicentric trials (Moncayo \& Luquetti 1990, Levin et al. 1991). Easier diagnosis encouraged scientists to monitor changes after treatment. Recognition that antibody levels could came down after successful etiological treatment during the acute phase, and even their abscence after a period of time, led to search the same phenomena in recently acquired chronic phase children, with the same results, i.e. abscence of antibodies against Trypanosoma cruzi after some years of follow up (Andrade et al. 1996, Sosa et al 1998). Today, the same holds for succesfully treated chronic phase adults, but the follow up should extent to some decades [review in Rev Pat Trop 27 (Supl.) 1998]. This is a clear example of the usefullness of laboratory tests in Chagas disease, appart from diagnosis. In this period, other tools started to be used, as the chemiluminescent assay (Almeida et al. 1994) and the fluorescent activated cell sorter (Martins-Filho et al. 1995).

Nowadays, high technology applied on serological techniques allow to use few steps with shorter incubation time, which permit to run an ELISA test in less than $1 \mathrm{hr}$, instead of $8 \mathrm{hr}$ when it was described. Other assays involve the use of recombinant antigens in strips, in a single step, with results in few minutes, as one developed by CYTED-BT (Bialy 1998). Nevertheless, performing two paralel assays is still necessary, since we lack of an universal antigen, recognized by all infected individuals. Responsability for true results has been increasing, avoiding both false positives or false negatives. Even if parasites are scarce, the tendency to look for circulating antigens with different methods, including PCR, will give in the near future, more basis for a true diagnosis. 


\section{REFERENCES}

Almeida IC, Rodrigues EG, Travassos LR 1994. Chemoluminescent immunoassays: discrimination between the reactivities of natural and human patients antibodies from eukaryotic pathogens, Trypanosoma cruzi and Paracoccidioides brasiliensis. $J$ Clin Lab Anal 8: 424-431.

Almeida JO, Fife Jr. EH 1976. Métodos de fijación del complemento estandarizado cuantitiativamente para la evaluación crítica de antígenos preparados com Trypanosoma cruzi. OPAS, Publ Cient. no. 319, Washington.

Andrade ALSS, Zicker F, Oliveira RM, Silva SA, Luquetti AO, Travassos LR, Almeida IC, Andrade SS, Andrade JG Martelli CMT 1996. Randomized trial of efficacy of benznidazole in treatment of early Trypanosoma cruzi infection. Lancet 348: 14071413.

Bialy H 1998. CYTED-BT: an international biotechnology network that works. Nature Biotechnol 16: 794.

Brumpt E 1914. Le xénodiagnostic. Application au diagnostic de quelques infections parasitaires et en particulier a la Trypanosomose de Chagas. Bull Soc Pat Exot 7: 706-710.

Camargo ME 1966. Fluorescent antibody test for the diagnosis of American trypanosomiasis. Technical modification employing preserved culture forms of Trypanosoma cruzi in a slide test. Rev Inst Med Trop São Paulo 8: 227-234.

Camargo MW, Amato Neto V 1974. Anti-Trypanosoma cruzi IgM antibodies as serological evidence of recent infection. Rev Inst Med Trop São Paulo 16: 200202.

Cerisola JA, Chaben MF, Lazari JO 1962. Test de hemaglutinación para el diagnóstico de la enfermedad de Chagas. Prensa Méd Argent 49: 17611767.

Chiari E, Brener Z 1966. Contribuição ao diagnóstico parasitológico da doença de Chagas na sua fase crônica. Rev Inst Med Trop São Paulo 8: 134-138.

Chiari E, Dias JCP, Lana M, Chiari CA 1989. Hemocultures for the parasitological diagnosis of human chronic Chagas disease. Rev Soc Bras Med Trop 22: 19-23.
Guerreiro C, Machado A 1913. Da reação de Bordet e Gengou na moléstia de Carlos Chagas como elemento diagnóstico. Brasil Med 27: 225-226.

Levin MJ, Franco da Silveira J, Frasch ACC, Camargo ME, Lafon S, Degrave WM, Rangel-Aldao R 1991. Recombinant Trypanosoma cruzi antigens and Chagas disease diagnosis: analysis of a workshop. FEMS Microbiol Immunol 89: 11-20.

Luz ZMP, Coutinho MC, Cançado JR, Krettli AU 1994. Hemocultura: técnica sensível na detecção do Trypanosoma cruzi em pacientes chagásicos na fase crônica da doença de Chagas. Rev Soc Bras Med Trop 27: 143-148.

Martins-Filho OA, Pereira MES, Carvalho JF, Cançado JR, Brener Z 1995. Flow cytometry, a new approach to detect anti-live trypomastigote antibodies and monitor the efficacy of specific treatment in human Chagas disease. Clin Diag Lab Immunol 2: 569-573.

Moncayo A, Luquetti AO 1990. Multicentre double blind study for evaluation of Trypanosoma cruzi defined antigens as diagnostic reagents. Mem Inst Oswaldo Cruz 85: 489-495.

Moser DR, Kirchhoff L, Donnelson JE 1989. Detection of Trypanosoma cruzi by DNA amplification using the polymerase chain reaction. J Clin Microbiol 27: 1477-1482.

Reunión sobre tratamiento etiológico en la fase crónica de la enfermedad de Chagas 1998. Rev Pat Trop 27(Supl.): 1-55.

Sosa Estani S, Segura EL, Ruíz AM, Velázquez E, Porcel BM, Yampotis C 1998. Efficacy of chemotherapy with benznidazole in children in the indeterminate phase of Chagas disease. Am J Trop Med Hyg 59: 526-529.

Strout RG 1962. A method for concentrating hemoflagellates. J Parasitol 48: 100.

Sturm NR, Degrave W, Morel C, Simpson L 1989. Sensitive detection and schizodeme classification of Trypanosoma cruzi cells by amplification of kinetoplast minicircle DNA sequences: use in diagnosis of Chagas disease. Mol Biochem Parsitol 33: 205214.

Voller A, Draper C, Bidwell DE, Bartlett AA 1975. Microplate enzyme-linked immunosorbent assay (ELISA) for Chagas disease. Lancet 1: 426-429. 